Review

\title{
Applications of Functionalized Fullerenes in Tumor Theranosties
}

\author{
Zhiyun Chen, Lijing Ma, Ying Liu凶 ${ }^{\bowtie}$, Chunying Chen
}

CAS Key Laboratory for Biomedical Effects of Nanomaterials and Nanosafety, National Center for Nanoscience and Technology, Beijing 100190, China.

Corresponding author: Dr. Ying Liu, CAS Key Laboratory for Biomedical Effects of Nanomaterials and Nanosafety, National Center for Nanoscience and Technology (NCNST), No.11, 1st North Street, Zhongguancun, Beijing 100190, China. Tel: +86-10-82545526; Fax: +86-10-62656765; E-mail: liuy@nanoctr.cn.

(c) Ivyspring International Publisher. This is an open-access article distributed under the terms of the Creative Commons License (http://creativecommons.org/ licenses/by-nc-nd/3.0/). Reproduction is permitted for personal, noncommercial use, provided that the article is in whole, unmodified, and properly cited.

Received: 2011.09.13; Accepted: 2011.11.02; Published: 2012.03.01

\begin{abstract}
Functionalized fullerenes with specific physicochemical properties have been developed for cancer diagnosis and therapy. Notably, metallofullerene is a new class of magnetic resonance imaging (MRI) contrast-enhancing agent, and may have promising applications for clinical diagnosis. Polyhydroxylated and carboxyl fullerenes have been applied to photoacoustic imaging. Moreover, in recent years, functionalized fullerenes have shown potential in tumor therapies, such as photodynamic therapy, photothermal treatment, radiotherapy and chemotherapeutics. Their antitumor effects may be associated with the modulation of oxidative stress, anti-angiogenesis, and immunostimulatory activity. While various types of novel nanoparticle agents have been exploited in tumor theranostics, their distribution, metabolism and toxicity in organisms have also been a source of concern among researchers. The present review summarizes the potential of fullerenes as tumor theranostics agents and their possible underlying mechanisms are discussed.
\end{abstract}

Key words: Functionalized fullerenes, nanoparticles, cancer diagnosis, cancer therapy, theranostics.

\section{Introduction}

Buckminsterfullerene $\left(\mathrm{C}_{60}\right)$ is a carbon allotrope discovered in 1985 [1]. Since then, fullerenes have attracted much attention and been widely investigated. After the main problem of poor solubility was solved by chemical or supramolecular approaches (usually a chemical modification on the surface of the sphere), various functionalized fullerenes were synthesized to achieve promising results [2]. For example, the empty interior cavity of the fullerene molecule makes it an ideal site for containment of a metal atom to form metallofullerene. This special structure of metallofullerene shows advantages compared to the metal itself or metal chelate complexes. One of their most important and novel electronic properties is the so-called intra-fullerene electron transfer from the encaged metal atom(s) to the fullerene cage(s), which has been suggested to use in MRI [3]. Most likely due to its unique chemical structure, $\mathrm{C}_{60}$ possesses interesting photo-physical properties and generates reactive oxygen species (ROS) by exposure to visible light, making it a potentially strong agent for photodynamic therapy in biological systems [4].

The specific physicochemical properties of fullerenes promoted the development of tumor theranostic; consequently, functionalized fullerenes are currently under extensive investigation due to their potential application to tumor imaging and therapy (Table 1). 
Table I. Application of various functionalized fullerenes to tumor theranostics.

\begin{tabular}{|c|c|c|c|c|}
\hline \multicolumn{2}{|c|}{ Applications } & \multirow{2}{*}{$\begin{array}{l}\text { Types of functionalized fullerenes } \\
\mathrm{Gd} @ \mathrm{C}_{82}(\mathrm{OH})_{40}\end{array}$} & \multirow{2}{*}{$\begin{array}{l}\text { Predominant characteristics } \\
\begin{array}{l}\text { higher signal enhancement at a dose of } 1 / 20 \text { of } \\
\text { commercial Gd-DTPA }\end{array}\end{array}$} & \multirow{2}{*}{$\begin{array}{l}\begin{array}{l}\text { Refer- } \\
\text { ences }\end{array} \\
{[10]}\end{array}$} \\
\hline $\begin{array}{l}\text { Cancer } \\
\text { diagno- }\end{array}$ & $\begin{array}{l}\text { Magnetic resonance } \\
\text { imaging (MRI) }\end{array}$ & & & \\
\hline & & $\mathrm{Gd} @ \mathrm{C}_{82} \mathrm{O}_{2}(\mathrm{OH})_{16}\left(\mathrm{C}\left(\mathrm{PO}_{3} \mathrm{Et}_{2}\right)_{2}\right)_{10}$ & high affinity to bone & {$[11]$} \\
\hline & & $\mathrm{Gd} @ \mathrm{C}_{60}\left[\mathrm{C}(\mathrm{COOH})_{2}\right]_{10}$ & $\begin{array}{l}\text { excellent cellular uptake efficiency without any ad- } \\
\text { junctive agent, obtained by a non-chromatographic } \\
\text { procedure with more abundant } \mathrm{M} @ \mathrm{C}_{60} \text { fraction }\end{array}$ & {$[13,14]$} \\
\hline & & $\mathrm{Gd}_{3} \mathrm{~N} @ \mathrm{C}_{80}\left[\mathrm{DiPEG}(\mathrm{OH})_{\mathrm{x}}\right]$ & the highest relaxivity & {$[15,16]$} \\
\hline & & $\begin{array}{l}\mathrm{Gd}_{3} \mathrm{~N} @ \mathrm{C}_{80}(\mathrm{OH})_{\sim 26}\left(\mathrm{CH}_{2} \mathrm{CH}_{2} \mathrm{COOM}\right)_{\sim 1} \\
6(\mathrm{M}=\mathrm{Na} \text { or } \mathrm{H})\end{array}$ & $\begin{array}{l}\text { readily synthesized with high yield, further qualified } \\
\text { diffusion time }\end{array}$ & {$[17]$} \\
\hline & & $\begin{array}{l}\mathrm{Gd} @ \mathrm{C}_{82} \mathrm{O}_{6}(\mathrm{OH})_{16}-\left(\mathrm{NHCH}_{2} \mathrm{CH}_{2} \mathrm{COO}\right. \\
\mathrm{H})_{8} \\
\mathrm{Gd}_{3} \mathrm{~N} @ \mathrm{C}_{80}(\mathrm{OH})_{26}\left(\mathrm{CH}_{2} \mathrm{CH}_{2} \mathrm{COOH}\right)_{16}\end{array}$ & $\begin{array}{l}\text { conjugated to an protein/peptide for "tumor tar- } \\
\text { geted" imaging }\end{array}$ & {$[18,19]$} \\
\hline & $\begin{array}{l}\text { Photoacoustic } \\
\text { ag- } \\
\text { ing(\&Photothermal } \\
\text { treatment) }\end{array}$ & $\mathrm{C}_{60}(\mathrm{OH})_{\times} \mathrm{O}_{y} \mathrm{Na}_{\mathrm{z}}$ & $\begin{array}{l}\text { "acoustic-explosion" after exposure to laser irradia- } \\
\text { tion }\end{array}$ & {$[20,21]$} \\
\hline \multirow[t]{11}{*}{$\begin{array}{l}\text { Cancer } \\
\text { therapy }\end{array}$} & $\begin{array}{l}\text { Photodynamic } \\
\text { therapy }\end{array}$ & $\mathrm{C}_{60}$ conjugated with $\mathrm{PEG}, /$ pullulan & $\begin{array}{l}\text { strong tumor suppression coupled with light irradi- } \\
\text { ation }\end{array}$ & {$[26,27]$} \\
\hline & & ${ }^{125} \mathrm{I}-\mathrm{C}_{60}(\mathrm{OH})_{\times}$ & accumulated in tumors readily and persistently & [28] \\
\hline & & $\mathrm{C}_{60}-\mathrm{PEG}-\mathrm{Gd}$ & $\begin{array}{l}\text { a good agreement between the time profile of the } \\
\text { PDT effect and the detection of positive MRI signal }\end{array}$ & [29] \\
\hline & & $(\gamma-\mathrm{CyD})_{2} / \mathrm{C}_{60}$ & singlet oxygen -mediated phototoxicity & {$[31,32]$} \\
\hline & & $\mathrm{C}_{60}$-porphyrin & $\begin{array}{l}\text { induce carcinoma cell death through either a } \\
{ }^{1} \mathrm{O}_{2} \text {-mediated photoreaction process or a free radical } \\
\text { mechanism }\end{array}$ & [33] \\
\hline & & $\begin{array}{l}\text { N-methylpyrrolidinium-fullerene } \\
\text { (BB4) }\end{array}$ & induce apoptosis by producing Type 1 ROS & {$[34,35]$} \\
\hline & Radiotherapy & ${ }^{212} \mathrm{~Pb} @ \mathrm{C}_{60}$ malonic acids & $\begin{array}{l}\text { stable during } \beta \text {-decay of }{ }^{212} \mathrm{~Pb} \text { to }{ }^{212} \mathrm{Bi} \text {, attenuates the } \\
\text { myelotoxicity of }{ }^{212} \mathrm{~Pb}\end{array}$ & {$[36]$} \\
\hline & & ${ }^{177} \mathrm{Lu}_{x} \mathrm{Lu}_{(3-\mathrm{x})} \mathrm{N} @ \mathrm{C}_{80}$ & conjugated to IL-13 for RIT & {$[37]$} \\
\hline & Chemotherapeutics & $\mathrm{Gd} @ \mathrm{C}_{82}(\mathrm{OH})_{22}$ & $\begin{array}{l}\text { efficiently inhibit the growth of murine } \mathrm{H} 22 \text { hepa- } \\
\text { toma with low toxicity, reverse tumor resistance by } \\
\text { enhancing the endocytosis of cisplatin via nanopar- } \\
\text { ticle-mediated penetration }\end{array}$ & {$[40,43]$} \\
\hline & & $\mathrm{C}_{60}(\mathrm{OH})_{x}$ & significant tumor inhibition, anti-metastatic activity & {$[41,42]$} \\
\hline & & $\mathrm{C}_{60}, \mathrm{C}_{60}(\mathrm{Nd})$ & induce autophagy-mediated chemosensitization & {$[44,62]$} \\
\hline
\end{tabular}

\section{Functionalized fullerenes for tumor imaging Magnetic resonance imaging}

Among many imaging strategies, such as optical imaging (OI), computed tomography (CT), MRI, ultrasound (US), and radionuclide imaging with positron emission tomography (PET) or single photon emission computed tomography (SPECT), MRI is a versatile, non-invasive medical diagnostic technique that can provide both physiological and anatomical information, while not requiring the use of ionizing radiation. In addition, in many applications it is often the most sensitive method available to depict soft tissues. Therefore, it has been extensively used for brain and central nervous system imaging, for assessing cardiac function and for detecting abnormal tissues such as tumors $[5,6]$. However, the difference between MR images of normal and abnormal tissues is often not large enough; therefore, specific exogenous contrast agents are often required to increase MR image quality and obtain higher resolution and sensitivity.

Paramagnetic metal ions, especially gadolinium $\left(\mathrm{Gd}^{3+}\right)$, have been proposed as MR contrast agents. Conventional T1 contrast agents have been developed in the form of more stable and less toxic metallochelates, including gadolinium(III) diethyltriaminepentaacetic acid (Gd(III)-DTPA) and gadolinium-tetraazacyclododecanetetraacetic acid (Gd(III)-DOTA), which are currently marketed as Omniscan ${ }^{\circledR}$ and ProHance ${ }^{\circledR}$, respectively $[6,7]$. However, for $\mathrm{Gd}^{3+}$ chelate complexes, the main limitation is the release of metal ions in vivo during metabolic processes and the subsequent toxicity. Since 
gadolinium-containing metallofullerenes were first used as excellent contrast agents for MRI with relatively high spatiotemporal resolution, they have attracted much attention for their potential application in clinical diagnosis. The $\mathrm{Gd}^{3+}$ ion was encapsulated in the fullerene cage, which is a structure that preserves the properties of the metal ion, avoids any leakage and thus prevents its dissociation in vivo [7]. After specific chemical modifications, various Gd@ $C_{n}$ $(n=60,82)$ derivatives have been developed and widely explored (Figure 1A, B and C) $[8,9]$.
$\mathrm{Gd} @ \mathrm{C}_{82}(\mathrm{OH})_{n}$ has shown a water proton relaxivity twenty times higher than the commercially available Gd-DTPA. After intravenous (iv) administration of $\mathrm{Gd} @ \mathrm{C}_{82}(\mathrm{OH})_{40}$ at a dose of $1 / 20$ of the typical clinical dose of Gd-DTPA, a higher signal enhancement was measured in vivo (Figure 2) [10]. To achieve better bio-distribution, modification of the fullerene cages with biologically active groups has often been proposed. For example, the organic phosphonate modified Gd@ $\mathrm{C}_{82} \mathrm{O}_{2}(\mathrm{OH})_{16}\left(\mathrm{C}_{(}\left(\mathrm{PO}_{3} \mathrm{Et}_{2}\right)_{2}\right)_{10}$ has exhibited high affinity to bone [11].

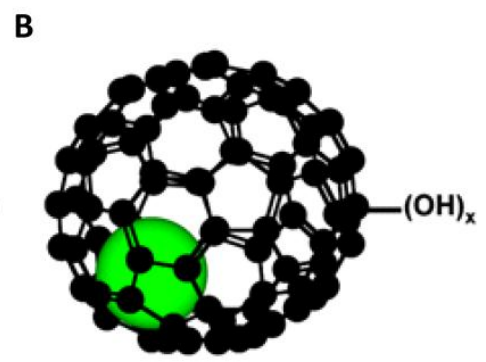

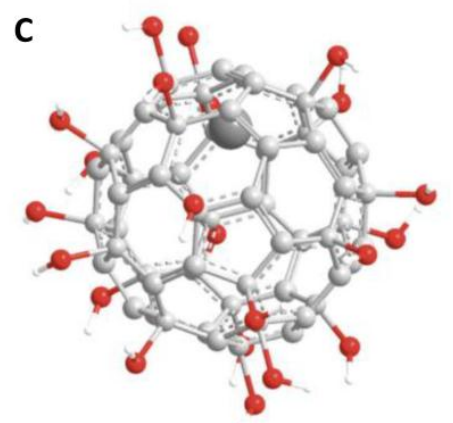

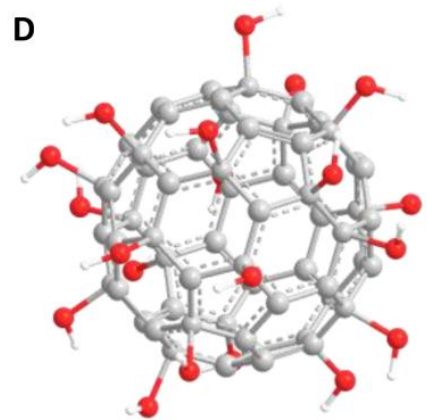

E

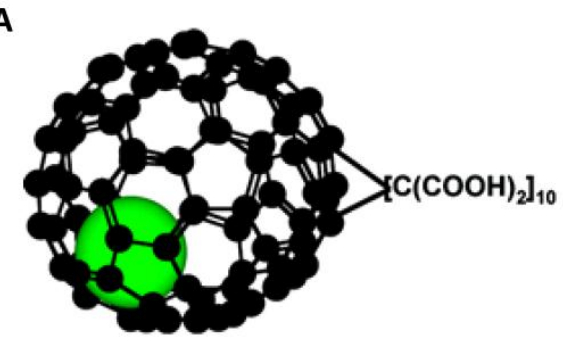

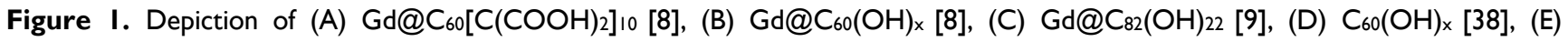
$\mathrm{C}_{60}\left[\mathrm{C}(\mathrm{COOH})_{2}\right]_{2}[39]$. Adapted with permission from [8].

A

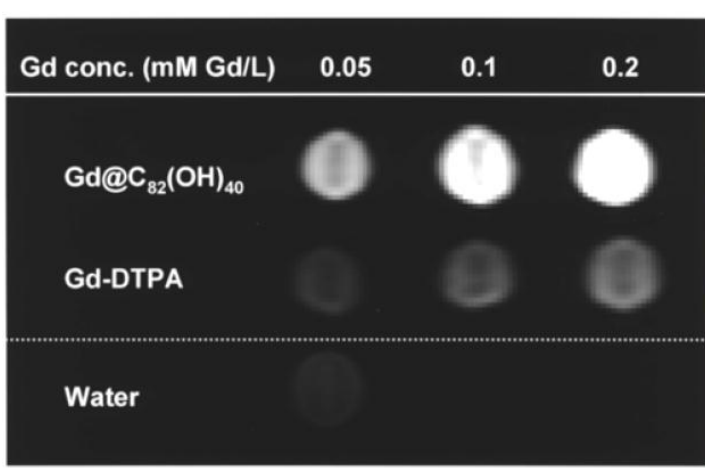

B

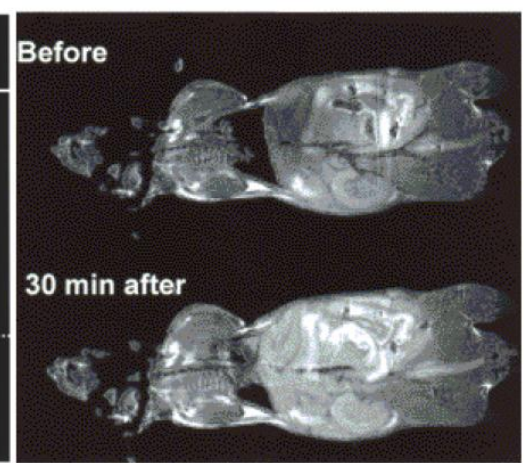

Figure 2. (A) TI-weighted MRI of (a)Gd@ $\mathrm{C}_{82}(\mathrm{OH})_{40}$ and Gd-DTPA phantom at a concentration of 0.05, 0.I, and 0.2 mmol Gd/L, (B) CDFI mice before and 30 min after i.v. administration of $\mathrm{Gd@} \mathrm{C}_{82}(\mathrm{OH})_{40}$ via tail vein as a dose of $5 \mu \mathrm{mol} \mathrm{Gd} / \mathrm{kg}[\mathrm{I0}]$. 
For a long time, the greatest obstacle to the practical application of Gd@ $\mathrm{C}_{82}$ was its low production yield and requirement for potentially laborious HPLC purification. Recently, without the complicated process of purification, Grushko et al. tested the MRI efficiency of a mixture of gadolinium endometallofullerenes (with high content of more than $80 \mathrm{~mol} . \%$ ) and empty fullerenes, and found that the T1-weighted signal intensity was 15 30 times higher than the commercial "Gadovist" contrast agent [12].

After the Gd@C $\mathrm{C}_{82}$ contrast agent was developed, another type of gadofullerene derivative, $\mathrm{Gd} @ \mathrm{C}_{60}\left[\mathrm{C}(\mathrm{COOH})_{2}\right]_{10}$ was also found to possess a higher relaxivity $\left(4.6 \mathrm{mM}^{-1} \mathrm{~s}^{-1}\right.$ at $20 \mathrm{MHz}$ and $\left.40{ }^{\circ} \mathrm{C}\right)$ compared to that of commercial $\mathrm{Gd}^{3+}$ chelate. It was used as an efficient cellular magnetic resonance imaging label in vitro and a 2.5 -fold signal enhancement was shown in T1-weighted MRI of labeled cells compared to control cells. The cellular uptake characteristics of this gadofullerene were significant and nonspecific, and an excellent labeling efficiency (98-100\%) was achieved without any adjunctive agent, compared to $\quad \mathrm{Gd} @ \mathrm{C}_{82}(\mathrm{OH})_{40}$. Furthermore, $\mathrm{Gd} @ \mathrm{C}_{60}\left[\mathrm{C}(\mathrm{COOH})_{2}\right]_{10}$ was the first highly soluble, air-stable discrete molecule based on the more abundant $\mathrm{M} @ \mathrm{C}_{60}$ fraction of metallofullerenes, obtaining by a non-chromatographic procedure $[13,14]$.

The $\mathrm{Gd}_{3} \mathrm{~N} @ \mathrm{C}_{80}$ fullerene exhibiting the highest relaxivity has seen wider use because of the presence of three $\mathrm{Gd}^{3+}$ ions per molecule. Functionalized trimetallic nitride endohedral metallofullerene species $\mathrm{Gd}_{3} \mathrm{~N} @ \mathrm{C}_{80}\left[\mathrm{DiPEG} 5000(\mathrm{OH})_{\times}\right]$has been used to perform high water hydrogen MR imaging relaxivity (R1) when used at a lower concentration, with an equivalent efficiency compared with commercial agents. After it was directly infused into a tumor bearing brain, improved tumor delineation was possible in comparison with the intravenously injected conventional $\mathrm{Gd}^{3+}$ chelate [15]. Zhang et al. also compared the ${ }^{1} \mathrm{H}$ MRI relaxivities of $\mathrm{Gd}_{3} \mathrm{~N} @ \mathrm{C}_{80}$ fullerenes with PEG of four different molecular weights (350-5000 Da), and found that 350/750 Da PEG derivatives exhibited the highest relaxivity compared to longer chain length ones, 5000 Da PEG derivatives [16]. At nearly the same time, $\mathrm{Gd}_{3} \mathrm{~N} @ \mathrm{C}_{80}(\mathrm{OH})_{26}\left(\mathrm{CH}_{2} \mathrm{CH}_{2} \mathrm{COOM}\right)_{16}(\mathrm{M}=\mathrm{Na}$ or $\mathrm{H})$ was readily synthesized by Shu et al. with high yield. The longitudinal and transverse relaxivities R1 and R2 were 50 times larger than those of $\mathrm{Gd}^{3+}$ poly(aminocarboxylate) complexes, such as commercial Omniscan and Magnevist. Furthermore, the new derivatives were more compact, diffused more slowly and lingered for a longer time than commercial agents and $\mathrm{Gd}_{3} \mathrm{~N} @ \mathrm{C}_{80}\left[\mathrm{PEG} 5000(\mathrm{OH})_{\mathrm{x}}\right]$ [17]. These results gave greater impetus to the development of metallofullerenes as MRI contrast agents.

In the previously mentioned studies, most imaging was obtained by directly administering fullerenes into tumor tissue, therefore tumor-targeting is certainly a subsequent challenge for tumor imaging. Antibodies of the green fluorescent protein (anti-GFP) were conjugated to endohedral gadofulleride, $\mathrm{Gd} @ \mathrm{C}_{82} \mathrm{O}_{6}(\mathrm{OH})_{16}-\left(\mathrm{NHCH}_{2} \mathrm{CH}_{2} \mathrm{COOH}\right)_{8}$, as a model for "tumor-targeted" imaging agents, and could be detected by using a fluorescent GFP probe. Results revealed that the antibody activity was well preserved after the conjugation, and the MRI activity was higher than that of unconjugated gadofulleride [18]. Recently, a more encouraging result was obtained. A carboxyl functionalized metallofullerene $\mathrm{Gd}_{3} \mathrm{~N} @ \mathrm{C}_{80}(\mathrm{OH})_{26}\left(\mathrm{CH}_{2} \mathrm{CH}_{2} \mathrm{COOH}\right)_{16}$ was successfully conjugated to an interleukin-13 (IL-13) peptide, the receptor of which was expressed on glioblastoma multiforme cells. This preliminary finding exhibited the potential of functionalized gadolinium metallofullerenes for tumor targeting and imaging [19].

\section{Photoacoustic imaging}

Recently, an attractive new therapeutic concept called 'acoustic-explosion' was suggested for some functionalized fullerenes, polyhydroxy fullerenes (PHF; $\mathrm{C}_{60}(\mathrm{OH})_{\times} \mathrm{O}_{\mathrm{y}} \mathrm{Na}_{\mathrm{z}}$ ) and carboxy fullerenes (CF; $\left.\mathrm{C}_{60}\left(\mathrm{C}(\mathrm{COOH})_{2}\right)_{3}\right)$. Concomitant with the exposure to low-intensity $\left(<10^{2} \mathrm{~W} \mathrm{~cm}^{-2}\right)$ continuous-wave laser irradiation in the presence or absence of oxygen, sustained glowing of functionalized fullerenes was observed. When this process was performed in cancer cells, a faint pop was heard following irradiation, indicating the photoacoustic properties of functionalized fullerenes. To investigate their potential for cancer imaging, researchers then used a mechanical scanning photoacoustic system with a single transducer to collect the acoustic signal, and embedded it in a phantom together with functionalized fullerenes. After laser irradiation in a water tank, high contrast photoacoustic images of functionalized fullerenes were obtained. Similarly, the photoacoustic imaging experiment yielded promising results in tumor-bearing nude mice. Excellent contrast between tumor and non-tumor regions was shown after intratumoral injection of PHF, and the laser energy used was only one-third of the maximum permissible exposure level of $29.5 \mathrm{~mJ} \mathrm{~cm}^{-2}$ for a $785 \mathrm{~nm}$ pulsed laser as established by the American National Standards Institute $[20,21]$. This new finding suggests potential applications of functionalized fullerenes for obtaining photoacoustic images (Figure 3). 
A

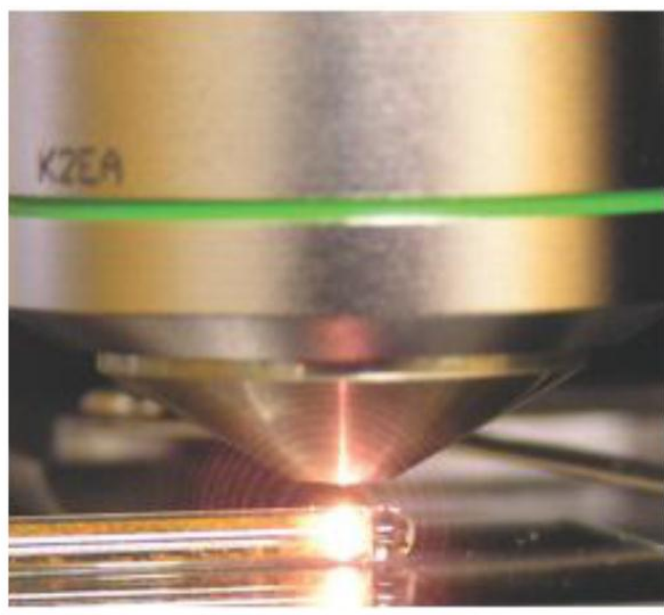

B
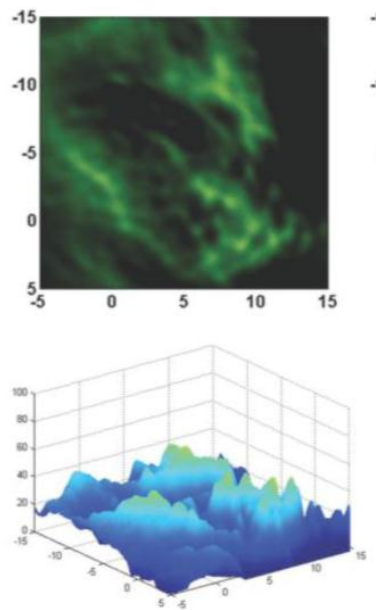
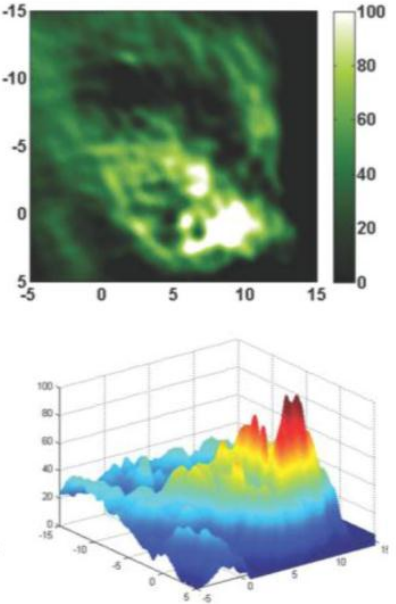

Figure 3. (A) Visible light emission from functionalized fullerenes irradiated with a 785-nm laser [2I]. (B) Photoacoustic imaging and 2-D signal mapping of tumors in living mice before (Left) and after (Right) intratumoral injection of polyhydroxy fullerenes [20].

\section{Functionalized fullerenes for tumor therapy Photodynamic therapy}

Photodynamic therapy (PDT) is a non-invasive treatment for various types of tumor. The combination of a photosensitizing agent and focused irradiation is used to elicit specific, controlled production of reactive oxygen species in a localized area, leading to cell destruction through several pathways. By using highly focused light irradiation, photodynamic therapy has the potential to act specifically at the desired site of action with low levels of collateral damage to healthy cells [22]. Fullerenes can efficiently generate reactive oxygen species when exposed to visible light, which means it may be an effective cytotoxic agent. The anatomical characteristics of tumor, such as hyperpermeable vasculature and an immature lymph system, make large-sized substances accumulate and remain longer in tumor tissues than in normal tissues. After the ideal molecular size, water-solubility, and tumor targeting were developed through various modifications, functionalized fullerenes are now available for cancer PDT both in tumor cells and tumor-bearing mice [23-25]. Many researches have been carried out to demonstrate this potential application of functionalized fullerenes.

When $\mathrm{C}_{60}$ was conjugated with polyethylene glycol (PEG), pullulan, etc., strong tumor suppression was shown after the conjugate was injected intravenously into tumor-bearing mice coupled with light irradiation [26, 27]. To confirm tumor uptake of $\mathrm{C}_{60}(\mathrm{OH})_{\times},{ }^{125} \mathrm{I}$-labeled fullerenol, ${ }^{125} \mathrm{I}-\mathrm{C}_{60}(\mathrm{OH})_{\times}$were administered to five tumor-bearing mice. The accu- mulation ratios of ${ }^{125} \mathrm{I}-\mathrm{C}_{60}(\mathrm{OH})_{\times}$in tumor compared to normal muscle tissue $(\mathrm{T} / \mathrm{N})$ and blood $(\mathrm{T} / \mathrm{B})$ at different time points revealed that $\mathrm{C}_{60}(\mathrm{OH})_{\times}$could be accumulated in several tumors readily and persistently, especially in mouse H22 hepatocarcinoma, suggesting that it could be used as a good photosensitizer in photodynamic tumor therapy [28]. To elevate the PDT effect by controlling the treatment time, $\mathrm{Gd}^{3+}$-chelated $\mathrm{C}_{60}$-PEG ( $\mathrm{C}_{60}$-PEG-Gd) was obtained from mixing gadolinium acetate solution with $\mathrm{C}_{60}$-PEG-DTPA, which was prepared by introducing diethylenetriaminepentaacetic acid (DTPA) to the terminal group of $\mathrm{C}_{60}$-PEG. The MRI activity was introduced into the $\mathrm{C}_{60}$-PEG of PDT photosensitizers by the chelate incorporation of $\mathrm{Gd}^{3+}$ ions and provided a non-invasive way to detect the time course of $\mathrm{C}_{60}$-PEG accumulating in the tumor tissue. There was good agreement between the time profile of the PDT effect and the detection of a positive MRI signal. These results indicated that $\mathrm{C}_{60}$ could be a potent photosensitizing agent for photodynamic tumor therapy after proper modifications [29].

Two oxidative mechanisms are considered to be mainly implicated in the photodamage of cells. One is free radicals and the other is singlet molecular oxygen $\left({ }^{1} \mathrm{O}_{2}\right)$, generated through electron transfer and energy transfer, respectively. These two mechanisms may be determined by some important factors. For example, $\mathrm{C}_{60}$ induced DNA cleavage occurs mainly through reduced active oxygen radicals such as superoxide anion radical $\left(\mathrm{O}_{2}^{-} \cdot\right)$ and hydroxyl radical $(\mathrm{OH})$ under physiological conditions, while ${ }^{1} \mathrm{O}_{2}$ was generated effectively in nonpolar solvents [30]. Besides, aggre- 
gation is a well-accepted factor that could deactivate the excited electronic states of photosensitizers and cause further loss of photoreactivity. Zhao et al. found that $\gamma$-cyclodextrin bicapped pristine $\mathrm{C}_{60}$ $\left[(\mathrm{\gamma}-\mathrm{CyD})_{2} / \mathrm{C}_{60}\right]$ was in a monomeric state in water whereas $\mathrm{C}_{60}(\mathrm{OH})_{24}$ was aggregated. It could be used to explain the phototoxicity induced by $(\gamma-C y D)_{2} / C_{60}$ toward human keratinocytes. The toxicity was mainly mediated by singlet oxygen and much higher than its water-soluble derivative $\mathrm{C}_{60}(\mathrm{OH})_{24}[31,32]$. Compared to Type 2 photochemistry mechanism, Type 1 is more depend on the surrounding oxygen concentration; thus, some functionalized fullerenes acting through the Type 1 pathway may be relatively more effective in hypoxic tumors. $\mathrm{C}_{60}$-porphyrin could induce HepG2 human larynx-carcinoma cell death through either a ${ }^{1} \mathrm{O}_{2}$-mediated photoreaction process or a free radical mechanism under anaerobic conditions [33]. $\mathrm{N}$-methylpyrrolidinium-fullerene (BB4) was found to be a powerful photosensitizer with the ability to kill cancer cells in vitro and in a mouse model of disseminated peritoneal carcinomatosis after illumination with white light. BB4 can induce apoptosis by pro-

A

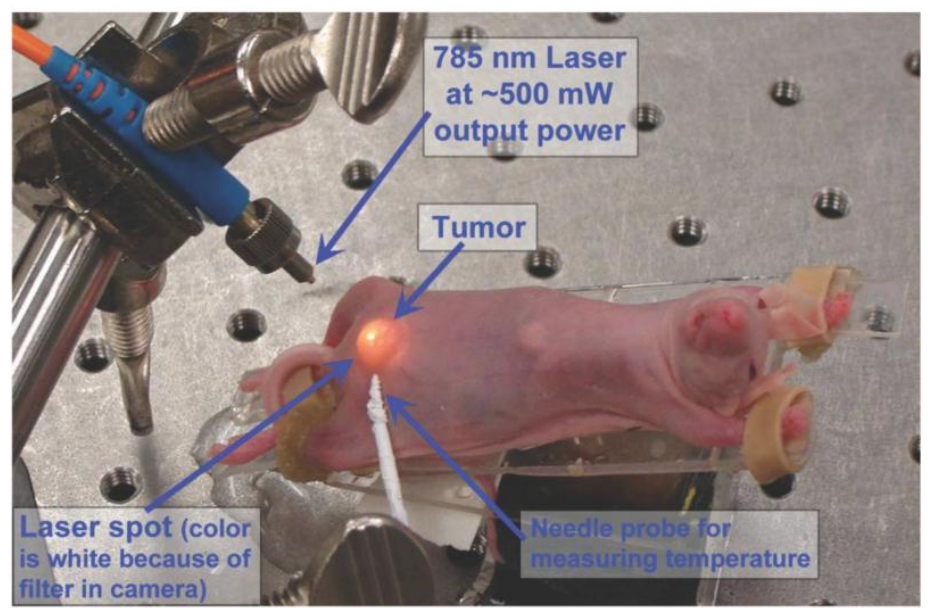

B

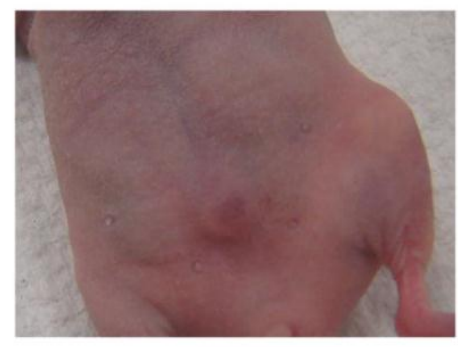

C

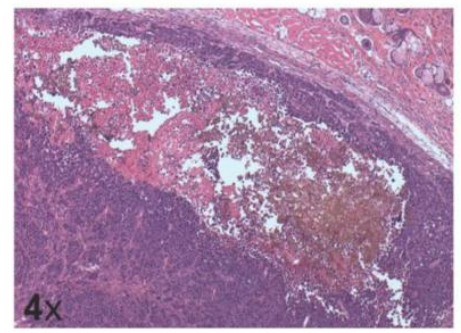

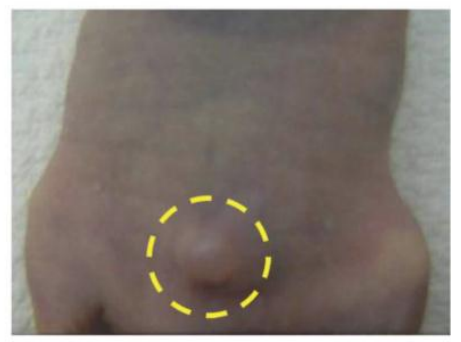

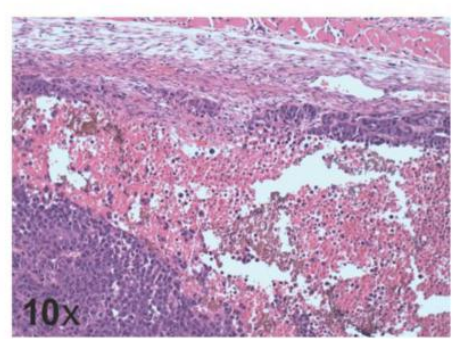

ducing Type 1 ROS, rather than singlet oxygen, i.e. a Type 2 mechanism [34, 35].

\section{Photothermal treatment}

Recently, certain functionalized fullerenes, especially polyhydroxy fullerenes (PHF) and carboxy fullerenes (CF) were found to be heated to their ignition temperature by exposure to low-intensity $\left(<10^{2}\right.$ $\mathrm{W} \mathrm{cm}{ }^{-2}$ ) continuous-wave laser irradiation, which was likely because of distortion of the symmetrical cage structure. This heating property would be extremely advantageous for cancer therapy, when a negatively charged PHF coating on silica nanoparticles functionalized with positively charged amine groups was dosed to A549 cells and localized destruction of cells was induced by irradiation with a near-infrared laser [21].

Moreover, when tumors were exposed to near-infrared light after injected with PHF nanoparticles, they decreased in cross-sectional area by an average of $32 \%$ within 2 hours of treatment, with only a blister visible 20 hours post-treatment. In addition, a concomitant faint audible sound was heard accompanied by bubble formation and bursting of the irradiated cells after exposure to a $785 \mathrm{~nm}$ laser. Thus, the rapid tumor shrinkage may be explained by both photothermal ablation and "acoustic-explosion" mechanisms (Figure 4) [20].

Figure 4. Treatment of a mice tumor with polyhydroxy fullerenes. (A) Experimental setup for photothermal ablation of tumor with CP-0.25 (chitosan-polyhydroxy fullerenes) nanoparticles. (B) Photographs of mouse tumor 2 hours (Left) and 20 hours (Right) after laser irradiation, only a blister was visible after 20 hours (within dotted lines). (C) Histological sections of remaining tumor stained with hematoxylin and eosin demonstrate areas of necrosis [20].

\section{Therapeutic Nuclear Medicine}

While the potential of metallofullerenes on MRI was developed vigorously, research on another application of functionalized fullerenes to therapeutic nuclear medicine was also performed. Based on a similar principle, metallic radionuclides encapsulated in fullerenes can be protected in the empty carbon cage stably, eliminating any undesired toxicity induced by the leakage and catabolism of administered radionuclides. 
The availability of radio-fullerenes in therapeutic nuclear medicine was then proven by distribution and stability evaluations. Diener et al. prepared the a-emitting ${ }^{212} \mathrm{~Pb} @ \mathrm{C}_{60}$ malonic acids for the first time and investigated the bio-distribution of the untargeted water-soluble radio-fullerene in mice and its stability during $\beta$-decay of ${ }^{212} \mathrm{~Pb}$ to ${ }^{212} \mathrm{Bi}$. It was shown that ${ }^{212} \mathrm{~Pb} @ \mathrm{C}_{60}$ malonate prevented the ${ }^{212} \mathrm{~Pb}$ from accumulation in bone, attenuated the myelotoxicity of ${ }^{212} \mathrm{~Pb}$, and exhibited a rather slow clearance. This radio-fullerene also appeared stable in solution (about $36 \%$ of the ${ }^{212} \mathrm{Bi}$ released) [36]. The above results suggested that water-soluble fullerenes might be suitable as cancer radiopharmaceuticals.

Effective targeted delivery of radionuclides is the primary challenge in radio-immunotherapy (RIT). By conjugating the radio-fullerenes with an antibody that is specific for receptors expressed preferentially on the cancer cells, radioisotopes can be delivered to cancer cells. After encapsulation of the $\beta$-emitter ${ }^{177} \mathrm{Lu}$ in a fullerene cage, an IL-13 peptide that targets an over-expressed receptor in glioblastoma multiforme tumors was successfully conjugated to the ${ }^{177} \mathrm{Lu}_{x} \mathrm{Lu}_{(3-\mathrm{x})} \mathrm{N} @ \mathrm{C}_{80}$ [37]. However, the efficiency of these radio-fullerenes for tumor targeting RIT requires further investigation in the living body or tumor cells.

\section{Chemotherapeutics}

Besides surgery, chemotherapeutics is another principal method for tumor therapy. However, the high toxicity and easily developed drug resistance considerably confine the chemotherapeutic effect. In recent years, functionalized fullerenes have been found to have some good characteristics to aid with antitumor treatments, and some of them have exhibited the potential for tumor inhibition (Figure 1C, D and E) $[9,38,39]$. In 2005, we found that gadolinium endohedral metallofullerenol $\left(\mathrm{Gd} @ \mathrm{C}_{82}(\mathrm{OH})_{\mathrm{n}}\right.$ nanoparticles) can efficiently inhibit the growth of murine H22 hepatoma without obviously adverse effects on important organs, having nearly no direct toxic effect to tumor cells [40], which is an advantage over conventional anti-tumor drugs. Zhu et al. [41] also tested the tumor-inhibitory effect of $\mathrm{C}_{60}(\mathrm{OH})_{\times}$on the same model. In the $\mathrm{C}_{60}(\mathrm{OH})_{x}$-treated group, significant tumor inhibition rates and reduced damage to liver were shown, in accordance to the histological results of inhibited tumor infiltration. Additionally, the anti-metastatic activities of fullerenol $\mathrm{C}_{60}(\mathrm{OH})_{20}$ was observed in cancer metastasis models [42]. Moreover, some fullerenes could increase the chemosensitization of tumor cells to chemotherapeutic agents and result in antitumor drug-mediated cell death, especially in some drug-resistant cancer cells $[43,44]$. Thereafter, great attention was focused on the underlying mechanisms of the antitumor activity of fullerenes as follows:

\section{I) Anti-angiogenesis}

Angiogenesis is one of the most important factors for the progression of tumor, by supplying tumors with oxygen and nutrients [45]. As tumors can generate their own blood vessels from the surrounding vasculature [46, 47], anti-angiogenesis treatments can inhibit growth and metastasis of various solid tumors [48].

Meng et al. investigated the anti-angiogenic activity of $\mathrm{Gd} @ \mathrm{C}_{82}(\mathrm{OH})_{22}$ and found that the nanoparticle can simultaneously down-regulate more than 10 angiogenic factors, which was confirmed in vivo by decreasing tumor microvessel density and lowering the nutrient supply to tumor tissues. A similar result was also obtained in another anti-angiogenesis study of $\mathrm{C}_{60}(\mathrm{OH})_{20}$ (Figure 5) [42, 49].

\section{2) Modulation of oxidative stress}

ROS such as superoxide radical anion, hydrogen peroxide, singlet oxygen, and hydroxyl radical, which can cause oxidative stress, are considered to be an important part in the mechanism of carcinogenesis. ROS can induce lipid peroxidation, protein fragmentation, DNA damage, damage to tumor-suppressor genes and enhance the expression of proto-oncogenes. It has been reported that various carcinoma cells synthesize ROS at an elevated rate in vitro, and many tumors are under persistent oxidative stress in vivo [42]. As water-soluble fullerenes showed high inhibitory activity on many kinds of tumor growth in mice, and it is well established that fullerenes and their derivatives possess a unique capacity for scavenging ROS [50], the relationship between the two functions of the nanoparticles was investigated.

The ROS scavenging capability of $\left[\mathrm{Gd} @ \mathrm{C}_{82}(\mathrm{OH})_{22}\right]_{\mathrm{n}}$ was verified by electron spin resonance (ESR) [51], as well as in tumor tissues of $\mathrm{C}_{60}(\mathrm{OH})_{20}$ treated mice [42], which meant that the antitumor mechanism of fullerenes may be related to its capacity to modulate oxidative stress in tumor-bearing models. On the other hand, Injac et al. found that fullerenol $\mathrm{C}_{60}(\mathrm{OH})_{24}$ had protective effects on the primary organs (heart, liver, lung and kidney) against chronic toxicity induced by doxorubicin, and thus may be useful as a potential organo-protector for anticancer therapy [52-55]. These results may increase the feasibility of applying fullerenes to cancer chemotherapeutics. 
3) Immunological activity

Our previous studies have demonstrated that water-soluble $\mathrm{C}_{60}(\mathrm{OH})_{20}$ and $\mathrm{Gd} @ \mathrm{C}_{82}(\mathrm{OH})_{22}$ nanoparticles have specific immunomodulatory effects on $\mathrm{T}$ cells and macrophages, and up-regulated the immune response in vivo, including the polarization of the cy- tokine balance towards Th1 (T-helper cell type 1) cytokines, which particularly increase TNF-a production, a very important factor helping to scavenge and kill tumor cells $[9,38]$. These results indicated effective immunological mechanisms of functionalized fullerenes (Figure 6).

A

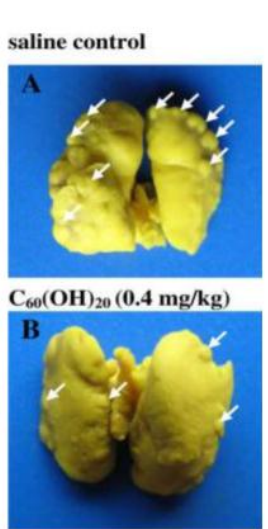

B $\mathrm{C}_{60}(\mathrm{OH})_{20}(2 \mathrm{mg} / \mathrm{kg})$
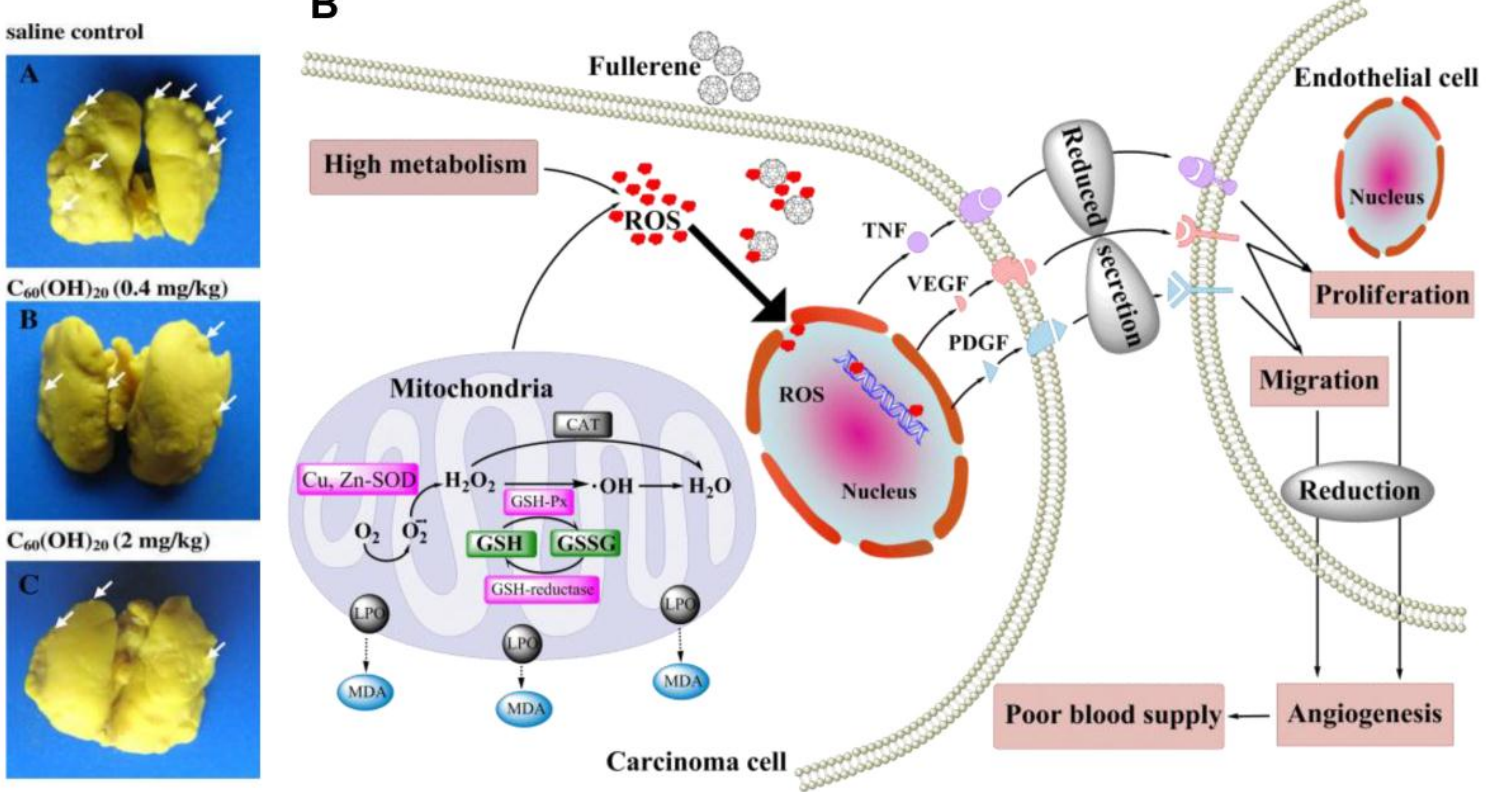

Figure 5. Mechanism by which $\mathrm{C}_{60}(\mathrm{OH})_{20}$ suppresses carcinoma metastasis in vivo. (A) (A-C) Photos of lungs after soaking in Bouin's solution showing spontaneous pulmonary breast cancer metastases (white arrows). (B) Administration of $\mathrm{C}_{60}(\mathrm{OH})_{20} \mathrm{can}$ decrease oxidative stress, the content of angiogenic factors(TNF- $\alpha$, VEGF and PDGF) and neovascularization in tumor tissues, inhibition of which diminish transmission of cancer cells to lung tissues [42].
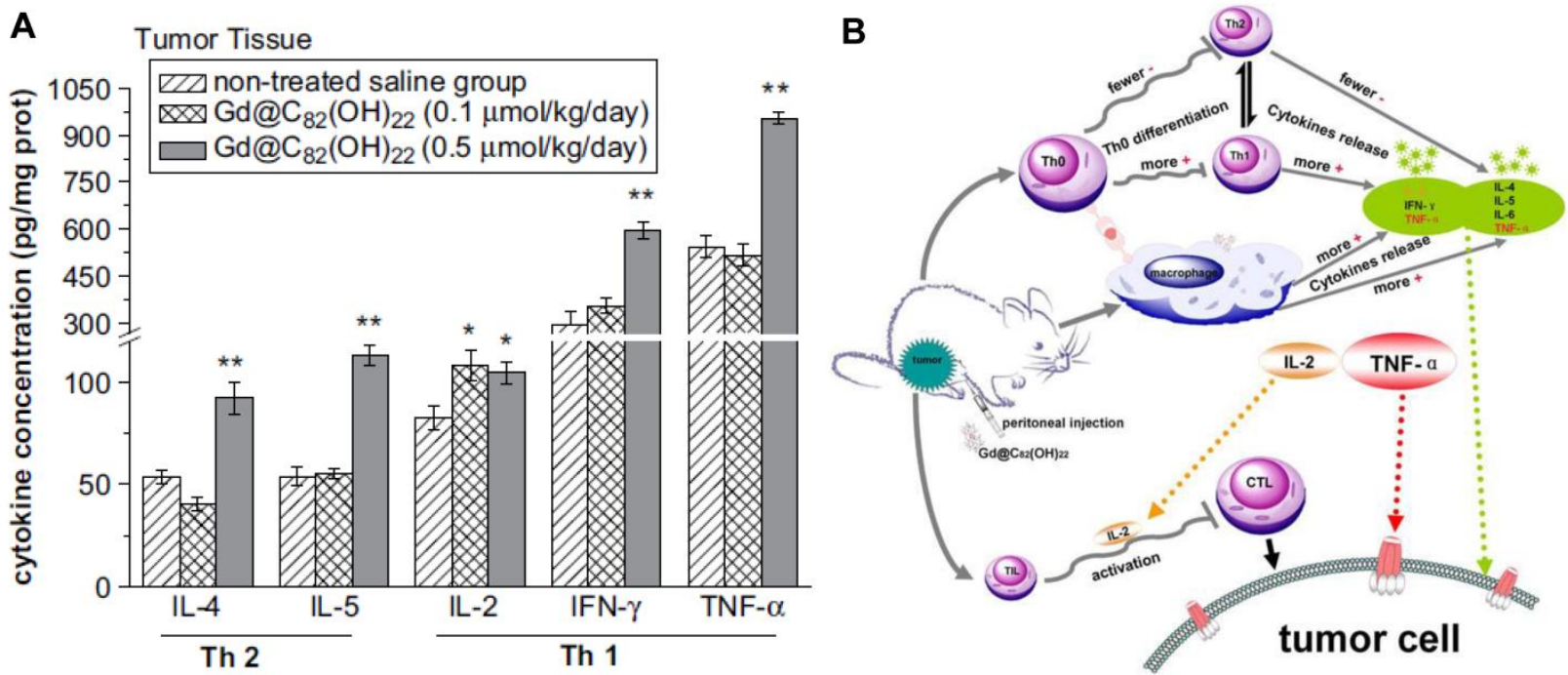

Figure 6. Possible immune-associated pathways by which $\mathrm{Gd@C} \mathrm{C}_{82}(\mathrm{OH})_{22}$ nanoparticles inhibit the growth of tumors. (A) In comparison to the untreated saline group, IFN- $y$ and TNF- $\alpha$ expression levels in mouse tumor tissues increased markedly in the group treated with $0.5 \mathrm{mmol} / \mathrm{kg} /$ day $\mathrm{Gd} @ \mathrm{C}_{82}(\mathrm{OH})_{22}$ nanoparticles. $(\mathrm{B}) T$ The $\mathrm{Gd} @ \mathrm{C}_{82}(\mathrm{OH})_{22}$ nanoparticles injected in the abdominal cavity are mostly engulfed by macrophages and other phagocytes through phagocytosis, whilst a few enter the blood directly through the peritoneum or mesentery. The Gd@ $\mathrm{C}_{82}(\mathrm{OH})_{22}$ nanoparticles stimulate macrophages and T cells to release several kinds of cytokines, such as, IL-2, IL-4, IL-5, TNF- $\alpha$ and IFN- $\gamma$, which then triggers a series of signal pathways of immune responses and possibly promotes tumor cell apoptosis [9]. 
Zhang et al. found that $\mathrm{Gd} @ \mathrm{C}_{82}(\mathrm{OH})_{22}$ could effectively activate dendritic cells (DCs) and macrophages, which are the most important antigen presenting cells (APC), as well as up-regulate the expression of co-stimulatory molecules and MHC molecules, thus enhancing the APC function of DCs and macrophages as illustrated by their capacity to activate allogeneic $\mathrm{T}$ cells. More evidence was also given to demonstrate the immune activity of $\mathrm{Gd} @ \mathrm{C}_{82}(\mathrm{OH})_{22}$, which could increase the production of Th1 cytokines and promote macrophages secreting pro-inflammatory cytokines such as IL-6 and TNF-a $[56,57]$.

Moreover, there are few reports about the antigenicity of $\mathrm{C}_{60}$ derivatives. Chen et al. found that mice immunized with the fullerene-bovine thyroglobulin conjugates generated a population of fullerene-specific antibodies of the IgG isotype, including a subpopulation that was cross-reacted with a $\mathrm{C}_{70}$ fullerene [58]. The specificity of the monoclonal antibody for the $\mathrm{C}_{60}$ fullerene was determined by competitive inhibition, and the anti- $\mathrm{C}_{60}$ antibodies were able to interact with single walled carbon nanotubes, which was imaged using atomic force microscopy $[59,60]$.

\section{4) Overcoming tumor resistance to chemotherapeutic drugs}

For cisplatin-resistant cancer (CP-r) cells, $\mathrm{Gd} @ \mathrm{C}_{82}(\mathrm{OH})_{22}$ alone had no obvious inhibition on tumor growth, although it has been indicated that the metallofullerene could improve the sensitivity of CP-r tumors to cisplatin, as an effective inhibition of CP-r tumors growth was observed following cisplatin plus nanoparticle treatment in vitro and in vivo. Transferrin-labeled experiments have shown that less intracellular transferrin is distributed in CP-r cells than in $\mathrm{CP}$-s cells, indicating a possible defective endocytosis of the CP-r cells. Since nanoparticles have been used as drugs or gene carriers for cancer treatment, it was posited that $\left[\mathrm{Gd} @ \mathrm{C}_{82}(\mathrm{OH})_{22}\right]_{\mathrm{n}}$ nanoparticles reverse tumor resistance by enhancing the endocytosis of cisplatin via nanoparticle-mediated penetration through the plasma membrane of the CP-r cells, and this hypothesis was confirmed by increased cisplatin adducts in NP and CP-treated CP-r cells measured by ICP-MS. Restoring defective endocytosis and other related possible mechanisms for overcoming tumor resistance to cisplatin by using fullerenes could lead to new chemotherapies for cancer [43].

\section{5) Autophagy-mediated chemo-sensitization}

The main therapeutic goal of cancer treatment is to trigger tumor-selective cell death. One of the cellular pathways receiving much attention in recent years is autophagy, a highly-regulated intracellular process for the degradation of long-lived proteins and damaged organelles. Autophagy can be either a cell death pathway or a cell survival pathway depending on many factors such as the degree of cell damage and intactness of apoptotic pathways [61]. Undoubtedly, promoting autophagy-mediated cell apoptosis is of most concern for tumor therapy.

Zhang et al. have performed comprehensive work on the modulation of autophagy in cancer cells by fullerene $\mathrm{C}_{60}$ nanocrystals. They found that HeLa cells treated with nano- $\mathrm{C}_{60}$ exhibited autophagic features, such as LC3 puncta formation, and many more autophagic vacuoles including autophagosomes and autolysosomes. Nano- $\mathrm{C}_{60}$ at non-cytotoxic concentrations sensitized chemotherapeutic killing of cancer cells in a photo-enhanced and ROS-dependent pathway, which was further verified via GFP-LC3 dot formation that was effectively reduced by free radical scavengers in the dark treatments [44]. A much greater potential in the induction of autophagy by another $\mathrm{C}_{60}$ derivative, $\mathrm{C}_{60}(\mathrm{Nd})$, was also reported [62]. All above results prompt that fullerenes might be available to be an efficient chemo-sensitizer in cancer therapy.

\section{Bio-distribution and Toxicity}

Although the diverse potential applications of fullerene and its derivatives have been exploited in cancer diagnosis and therapy, it is necessary to consider their biocompatibility and toxicity for organisms prior to their widespread utilization and production. Since fullerene derivatives with different modifications have distinct biological behaviors, understanding these will help in the safe development of fullerene-based drugs [63, 64].

\section{Bio-distribution and excretion}

The dynamic distribution of fullerenes within the body is influenced by several factors, including the particle size, various modifications, and administration pathways. Studying these factors can help to identify potential target tissues of fullerene and assess the toxicity at particular target sites.

Unlike oral administration, whereby ${ }^{14} \mathrm{C}$-labeled $\mathrm{C}_{60}$ is not efficiently absorbed and excreted primarily in the feces, $\mathrm{C}_{60}$ injected intravenously was cleared from the blood circulation rapidly, accumulated mainly within the liver and remained there for a long time, and then was cleared slowly from the liver (nearly all was eliminated 13 days after injection). All these results suggest that the liver is a potential target for fullerene accumulation and toxicity contributes to the metabolism of $\mathrm{C}_{60}\left(\mathrm{C}_{60}\right.$ metabolites were identified 
within the liver) and facilitates the removal of fullerenes from the body within the feces [65-67]. By comparison, the water-soluble $\mathrm{C}_{60}$ had a wider tissue distribution, which might be attributed to its more hydrophilic water-soluble character. ${ }^{99} \mathrm{mTc}_{\mathrm{T}} \mathrm{C}_{60}(\mathrm{OH})_{\times}$injected into mice through tail veins was quickly distributed to all organs except for tissues with limited blood flow, such as muscle. It remained throughout the $48 \mathrm{~h}$ of the study, particularly in the kidneys, bone, spleen and liver, and displayed a slow clearance rate except for bone, which showed slightly increasing accumulation within $24 \mathrm{~h}$ [68]. This phenomenon was further demonstrated by studying the distribution of ${ }^{125} \mathrm{I}_{-} \mathrm{C}_{60}(\mathrm{OH})_{\times}$, which was rapidly distributed to all organs (mainly in the kidneys, liver, bone, spleen and stomach) through the blood circulation and especially exhibited a rapid and high uptake in kidneys, followed by a fast excretion into urine. Likewise, ${ }^{125} \mathrm{I}-\mathrm{C}_{60}(\mathrm{OH})_{\times}$was not found in the brain, suggesting it could not penetrate the blood-brain barrier (BBB), which was different from the $\mathrm{C}_{60}$ modified with dipolar trimethylenemethane [28].

Similarly, Cagle et al. [69] found that ${ }^{166} \mathrm{Ho} @ \mathrm{C}_{82}(\mathrm{OH})_{\mathrm{y}}$ was distributed throughout the entire body, except for the brain and fat tissues, as early as $1 \mathrm{~h}$ after the tail-vein injection, which was different from the finding with metal chelate $\left(\mathrm{Na}_{2}\left[{ }^{166} \mathrm{Ho}(\mathrm{DTPA})\left(\mathrm{H}_{2} \mathrm{O}\right)\right]\right)$. Only the concentrations of ${ }^{166} \mathrm{Ho}$ in liver and bone increased from 1 to $4 \mathrm{~h}$, especially in bone, which subsequently displayed a slight increase in concentration over $48 \mathrm{~h}$ (Figure 7A). These results were consistent with the observations for the bio-distribution of $\left[\mathrm{Gd} @ \mathrm{C}_{82}(\mathrm{OH})_{22}\right]_{\text {n }}$ particles. Unlike $\mathrm{GdCl}_{3}$, $\left[\mathrm{Gd} @ \mathrm{C}_{82}(\mathrm{OH})_{22}\right]_{\mathrm{n}}$ was delivered to almost all observed tissues, but accumulated mostly in bone, suggesting that the fullerene cage could not be destroyed in organisms and that the internal $\mathrm{Gd}^{3+}$ was well protected in the cage. The concentration of $\mathrm{Gd}$ in the brain was close to the baseline, suggesting that the $\left[\mathrm{Gd} @ \mathrm{C}_{82}(\mathrm{OH})_{22}\right]_{\mathrm{n}}$ nanoparticles could not pass through the BBB either (Figure 7B) [70]. The similar results for the bio-distributions of $\mathrm{C}_{60}(\mathrm{OH})_{\times}$and $\mathrm{C}_{82}(\mathrm{OH})_{\mathrm{y}}$ showed that the biological properties would not be expected to change by incorporation of a metal atom within a fullerene cage. Thus, distribution and biocompatibility of fullerenes were usually assessed through ip and iv injections, and chemical modification to the fullerene cages may play an important role in determining their distribution and biocompatibility.
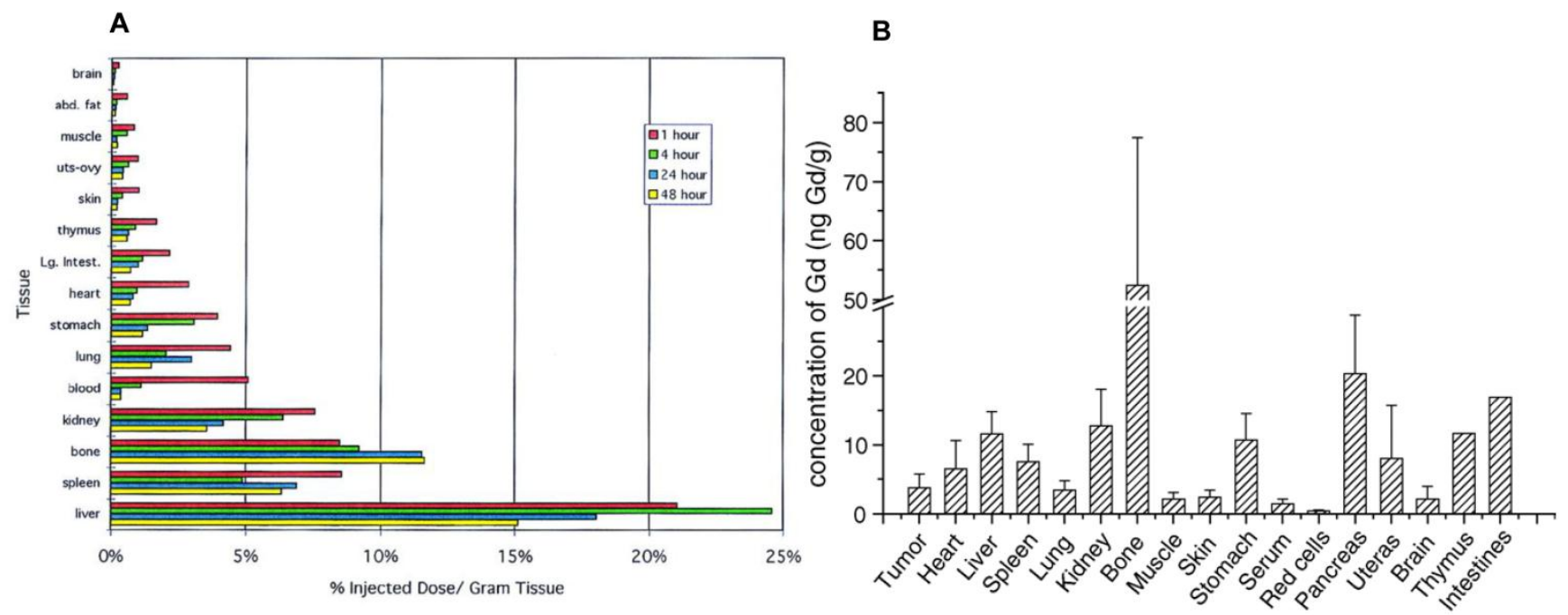

Figure 7. (A) Biodistribution of $166 \mathrm{Ho} \mathrm{o}_{x} @ \mathrm{C}_{82}(\mathrm{OH})_{y}$ in $\mathrm{BALB} / \mathrm{c}$ mice at $\mathrm{I}, 4,24$, and $48 \mathrm{~h}$ after injection. The animals were sacrificed, and organs were sampled at I, 4, 24, and $48 \mathrm{~h}$, followed by measurement of the $166 \mathrm{Ho} 80.5 \mathrm{KeV} \gamma$-emission [69]. (B) Biodistribution of $\left[\mathrm{Gd} @ \mathrm{C}_{82}(\mathrm{OH})_{22}\right]_{\mathrm{n}}$ nanoparticles in tumor-bearing mice (expressed as concentrations of gadolinium element, ng Gd/g wet weight) [70].

\section{Toxicity evaluation}

To understand the toxicity of $\mathrm{C}_{60}$, it is usually necessary to investigate the lethality, gross or microscopic lesions, histopathological change, etc. However, other biological responses, such as stimulation of the immune system, regulation of oxidative stress, and changes on the molecular level induced by fullerenes, should generally be considered as well.

Following the inhalation pathway, $\mathrm{C}_{60}$ and its derivates can be partly deposited in the lungs and internalized by alveolar macrophages; a pulmonary inflammatory response was elicited for a high exposure dose of fullerenols $(10 \mathrm{mg} / \mathrm{kg})$ and fullerenols at 
low concentrations (1 $\mathrm{mg} / \mathrm{kg})$ exhibited an anti-inflammatory property. Although slight changes in gene expression level were observed, no obviously toxicity was reported [71, 72]. Only when water-soluble polyalkylsulfonated $\mathrm{C}_{60}$ was administrated at extremely high dose $\left(\mathrm{LD}_{50}=600 \mathrm{mg} / \mathrm{kg}\right)$ in an acute toxicity study or at a moderately high dose (up to 60 $\mathrm{mg} / \mathrm{kg}$ ) via ip injection, observable pathological or lethal toxicity was induced. However, in subsequent study of oral exposure, fullerenes were considered to be nontoxic at a dose of $50 \mathrm{mg} / \mathrm{kg}$, which was close to that of ip administration [73]. Even when the dose was increased to $2,000 \mathrm{mg} / \mathrm{kg}$, fullerite (a mixture of $\mathrm{C}_{60}$ and $\mathrm{C}_{70}$ ) has not shown to cause any acute toxicity. The possible reason is that fullerenes are not effectively absorbed through the alimentary tract [74]. Toxicity assessment of fullerenes should therefore be considered comprehensively, including the exposure routes and the delivered dose, etc.

After fullerenes enter into the body, they may be internalized by different types of cells, and induce various changes inside the cells, such as viability, proliferation, inflammation responses, and oxidative responses. Therefore, the cytotoxicity assessment of fullerenes has been one of the most important aspects to consider when assessing the toxicity of fullerenes [75]. Many related studies have been performed on various cell lines. $\mathrm{C}_{60}$ and quaternary ammonium derivatized $\mathrm{C}_{60}$ inhibited keratinocytes proliferation at a concentration of $2 \mu \mathrm{M}$ and over a period of 8 days, which is relatively long [66]. In both human skin (HDF) and liver carcinoma (HepG2) cells, water-soluble fullerene species are less cytotoxic than pristine $\mathrm{C}_{60}$, while $\mathrm{C}_{60}(\mathrm{OH})_{24}$ showed no cytotoxicity up to its limits of solubility, suggesting the functional groups on the surface of a fullerene molecule can dramatically decrease the toxicity. However, $\mathrm{C}_{60}(\mathrm{OH})_{24}$ was found to induce cytotoxic morphological changes within the HUVEC cell line in a dose-dependent way, and only maximal doses of fullerenes caused cytotoxic injury and/or death and inhibited cell growth [76]. In nearly every fullerene-related anti-tumor study, fullerenes were not found to have a direct influence on tumor cell viability $[9,38,40,42]$. The diverse toxicity results of fullerenes reveal that the sensitivity of various tissues or cells to the nanoparticles can be different. Therefore, thorough toxicity evaluation of fullerenes before their clinical application is necessary.

\section{Perspectives}

Due to their attractive physical, chemical, and biological properties and the availability of various methods for surface modification, fullerenes and their derivatives have been studied for their numerous biomedical applications, not only in tumor diagnosis and therapy, but also as an anti-HIV agent [77, 78], antimicrobial photosensitizer [79, 80], antioxidants $[52,81,82]$, and gene vector [83-85]. Some properties involved in these applications might create new insights into fullerenes as anti-tumor therapeutics, for example, in gene therapy. However, since the underlying mechanisms related to their apparent activities are not yet clear, further research towards a better understanding is urgently needed to investigate the biocompatibility and safe application of functionalized fullerenes as diagnostic tools and therapeutic agents.

\section{Acknowledgments}

We thank the Ministry of Science and Technology of China (National Basic Research Program: 2011CB933401 and 2010CB934004) and the National Science Foundation of China (21001034 and 10975040) for financial support.

\section{Conflict of Interest}

The authors have declared that no conflict of interest exists.

\section{References}

1. Kroto HW, Heath JR, O'Brien SC, et al. C60: Buckminsterfullerene. Nature. 1985; 318: 162-3.

2. Bosi S, Da Ros T, Spalluto G, et al. Fullerene derivatives: an attractive tool for biological applications. Eur J Med Chem. 2003; 38: 913-23.

3. Kato H, Kanazawa Y, Okumura M, et al. Lanthanoid endohedral metallofullerenols for MRI contrast agents. J Am Chem Soc. 2003; 125: 4391-7.

4. Arbogast JW, Darmanyan AP, Foote CS, et al. Photophysical properties of C60. J Phys Chem. 1991; 95: 11-2.

5. Liu Z, Kiessling F, Gatjens J. Advanced nanomaterials in multimodal imaging: design, functionalization, and biomedical applications. J Nanomater. 2010.

6. Na HB, Hyeon T. Nanostructured T1 MRI contrast agents. J Mater Chem. 2009; 19: 6267-73.

7. Mody VV, Nounou MI, Bikram M. Novel nanomedicine-based MRI contrast agents for gynecological malignancies. Adv Drug Del Rev. 2009; 61: 795-807.

8. Sitharaman B, Bolskar RD, Rusakova $\mathrm{I}$, et al. Gd@C60[C(COOH)2]10 and Gd@C60(OH)x: Nanoscale aggregation studies of two metallofullerene MRI contrast agents in aqueous solution. Nano Lett. 2004; 4: 2373-8.

9. Liu Y, Jiao F, Qiu Y, et al. The effect of Gd@C82(OH)22 nanoparticles on the release of Th1/Th2 cytokines and induction of TNF-alpha mediated cellular immunity. Biomaterials. 2009; 30: 3934-45.

10. Mikawa M, Kato H, Okumura $M$, et al. Paramagnetic water-soluble metallofullerenes having the highest relaxivity for MRI contrast agents. Bioconjug Chem. 2001; 12: 510-4.

11. Shu CY, Wang CR, Zhang JF, et al. Organophosphonate functionalized Gd@C82 as a magnetic resonance imaging contrast agent. Chem Mater. 2008; 20: 2106-9. 
12. Grushko YS, Kozlov VS, Sedov VP, et al. MRI-contrasting system based on water-soluble fullerene/Gd-metallofullerene mixture. Fuller Nanotub Car N. 2010; 18: 417-21.

13. Bolskar RD, Benedetto AF, Husebo LO, et al. First soluble M@C60 derivatives provide enhanced access to metallofullerenes and permit in vivo evaluation of Gd@C60[C(COOH)2]10 as a MRI contrast agent. J Am Chem Soc. 2003; 125: 5471-8.

14. Sitharaman B, Tran LA, Pham QP, et al. Gadofullerenes as nanoscale magnetic labels for cellular MRI. Contrast Media Mol Imaging. 2007; 2: 139-46.

15. Fatouros PP, Corwin FD, Chen ZJ, et al. In vitro and in vivo imaging studies of a new endohedral metallofullerene nanoparticle. Radiology. 2006; 240: 756-64.

16. Zhang JF, Fatouros PP, Shu CY, et al. High relaxivity trimetallic nitride $(\mathrm{Gd} 3 \mathrm{~N})$ metallofullerene MRI contrast agents with optimized functionality. Bioconjug Chem. 2010; 21: 610-5.

17. Shu CY, Corwin FD, Zhang JF, et al. Facile preparation of a new gadofullerene-based magnetic resonance imaging contrast agent with high (1)H relaxivity. Bioconjug Chem. 2009; 20: 1186-93.

18. Shu CY, Ma XY, Zhang JF, et al. Conjugation of a water-soluble gadolinium endohedral fulleride with an antibody as a magnetic resonance imaging contrast agent. Bioconjug Chem. 2008; 19: $651-5$

19. Fillmore HL, Shultz MD, Henderson SC, et al. Conjugation of functionalized gadolinium metallofullerenes with IL-13 peptides for targeting and imaging glial tumors. Nanomedicine. 2011; 6: 449-58.

20. Krishna V, Singh A, Sharma P, et al. Polyhydroxy fullerenes for non-invasive cancer imaging and therapy. Small. 2010; 6: 2236-41.

21. Krishna V, Stevens N, Koopman B, et al. Optical heating and rapid transformation of functionalized fullerenes. Nat Nanotechnol. 2010; 5: 330-4.

22. Satoh M, Takayanag I. Pharmacological studies on Fullerene(C60), a novel carbon allotrope, and its derivatives. J Pharmacol Sci. 2006; 100: 513-8.

23. Tabata Y, Ikada Y. Biological functions of fullerene. Pure Appl Chem. 1999; 71: 2047-53.

24. Tokuyama H, Yamago S, Nakamura E, et al. Photoinduced biochemical-activity of fullerene carboxylic-acid. J Am Chem Soc. 1993; 115: 7918-9.

25. Nakajima N, Nishi C, Li FM, et al. Photo-induced cytotoxicity of water-soluble fullerene. Fullerene Sci Technol. 1996; 4: 1-19.

26. Liu J, Tabata Y. Photodynamic therapy of fullerene modified with pullulan on hepatoma cells. J Drug Target. 2010; 18: 602-10.

27. Liu J, Tabata Y. Photodynamic antitumor activity of fullerene modified with poly(ethylene glycol) with different molecular weights and terminal structures. J Biomater Sci Polym Ed. 2011; 22: 297-312.

28. Ji ZQ, Sun HF, Wang HF, et al. Biodistribution and tumor uptake of $\mathrm{C} 60(\mathrm{OH}) \mathrm{x}$ in mice. J Nanopart Res. 2006; 8: 53-63.

29. Liu J, Ohta S, Sonoda A, et al. Preparation of PEG-conjugated fullerene containing Gd3+ ions for photodynamic therapy. J Control Release. 2007; 117: 104-10.

30. Yamakoshi Y, Umezawa N, Ryu A, et al. Active Oxygen Species Generated from Photoexcited Fullerene (C60) as Potential Medicines: O2-• versus 1O2. J Am Chem Soc. 2003; 125: 12803-9.

31. Zhao B, He YY, Bilski PJ, et al. Pristine (C60) and Hydroxylated [C60(OH)24] Fullerene Phototoxicity towards HaCaT Keratinocytes: Type I vs Type II Mechanisms. Chem Res Toxicol. 2008; 21: 1056-63.

32. Zhao B, Bilski PJ, He YY, et al. Photo-induced Reactive Oxygen Species Generation by Different Water-soluble Fullerenes (C60) and Their Cytotoxicity in Human Keratinocytes. Photochem Photobiol. 2008; 84: 1215-23.

33. Alvarez MG, Prucca C, Milanesio ME, et al. Photodynamic activity of a new sensitizer derived from porphyrin-C60 dyad and its biological consequences in a human carcinoma cell line. Int J Biochem Cell Biol. 2006; 38: 2092-101.

34. Mroz P, Pawlak A, Satti M, et al. Functionalized fullerenes mediate photodynamic killing of cancer cells: Type I versus Type II photochemical mechanism. Free Radical Biol Med. 2007; 43: 711-9.

35. Mroz P, Xia Y, Asanuma D, et al. Intraperitoneal photodynamic therapy mediated by a fullerene in a mouse model of abdominal dissemination of colon adenocarcinoma. Nanomedicine. 2011; Doi:10.1016/j.nano.2011.04.007.

36. Diener MD, Alford JM, Kennel SJ, et al. Pb-212@C60 and its water-soluble derivatives: Synthesis, stability, and suitability for radioimmunotherapy. J Am Chem Soc. 2007; 129: 5131-8.

37. Shultz MD, Duchamp JC, Wilson JD, et al. Encapsulation of a radiolabeled cluster inside a fullerene cage, 177LuxLu(3-x)N@C80: an interleukin-13-conjugated radiolabeled metallofullerene platform. J Am Chem Soc. 2010; 132: 4980-1.

38. Liu Y, Jiao F, Qiu Y, et al. Immunostimulatory properties and enhanced TNF- $\alpha$ mediated cellular immunity for tumor therapy by $\mathrm{C} 60(\mathrm{OH}) 20$ nanoparticles. Nanotechnology. 2009; 20: 415102-11.

39. Li W, Zhao L, Wei T, et al. The inhibition of death receptor mediated apoptosis through lysosome stabilization following internalization of carboxyfullerene nanoparticles. Biomaterials. 2011; 32: 4030-41.

40. Chen C, Xing G, Wang J, et al. Multihydroxylated [Gd@C82(OH)22]n nanoparticles: antineoplastic activity of high efficiency and low toxicity. Nano Lett. 2005; 5: 2050-7.

41. Zhu JD, Ji ZQ, Wang J, et al. Tumor-inhibitory effect and immunomodulatory activity of fullerol $\mathrm{C} 60(\mathrm{OH}) x$. Small. 2008; 4: 1168-75.

42. Jiao F, Liu Y, Qu Y, et al. Studies on anti-tumor and antimetastatic activities of fullerenol in a mouse breast cancer model. Carbon. 2010; 48: 2231-43.

43. Liang XJ, Meng H, Wang YZ, et al. Metallofullerene nanoparticles circumvent tumor resistance to cisplatin by reactivating endocytosis. Proc Natl Acad Sci U S A. 2010; 107: 7449-54.

44. Zhang Q, Yang WJ, Man N, et al. Autophagy-mediated chemosensitization in cancer cells by fullerene C60 nanocrystal. Autophagy. 2009; 5: 1107-17.

45. Folkman J. Tumor angiogenesis: therapeutic implications. N Engl J Med. 1971; 285: 1182-6.

46. Wang R, Chadalavada $\mathrm{K}$, Wilshire J, et al. Glioblastoma stem-like cells give rise to tumour endothelium. Nature. 2010; 468: 829-33.

47. Ricci-Vitiani L, Pallini R, Biffoni M, et al. Tumour vascularization via endothelial differentiation of glioblastoma stem-like cells. Nature. 2010; 468: 824-8.

48. Kou B, Li Y, Zhang L, et al. In vivo inhibition of tumor angiogenesis by a soluble VEGFR-2 fragment. Exp Mol Pathol. 2004; 76: 129-37.

49. Meng H, Xing G, Sun B, et al. Potent angiogenesis inhibition by the particulate form of fullerene derivatives. ACS Nano. 2010; 4: 2773-83.

50. Yin JJ, Lao F, Fu PP, et al. The scavenging of reactive oxygen species and the potential for cell protection by functionalized fullerene materials. Biomaterials. 2009; 30: 611-21.

51. Yin JJ, Lao F, Meng J, et al. Inhibition of tumor growth by endohedral metallofullerenol nanoparticles optimized as reactive oxygen species scavenger. Mol Pharmacol. 2008; 74: 1132-40.

52. Injac R, Perse M, Obermajer N, et al. Potential hepatoprotective effects of fullerenol $\mathrm{C} 60(\mathrm{OH}) 24$ in doxorubicin-induced hepa- 
totoxicity in rats with mammary carcinomas. Biomaterials. 2008; 29: 3451-60.

53. Injac $R$, Perse $M$, Cerne $M$, et al. Protective effects of fullerenol $\mathrm{C} 60(\mathrm{OH}) 24$ against doxorubicin-induced cardiotoxicity and hepatotoxicity in rats with colorectal cancer. Biomaterials. 2009; 30: $1184-96$.

54. Injac R, Boskovic $M$, Perse $M$, et al. Acute doxorubicin nephrotoxicity in rats with malignant neoplasm can be successfully treated with fullerenol $\mathrm{C} 60(\mathrm{OH}) 24$ via suppression of oxidative stress. Pharmacol Rep. 2008; 60: 742-9.

55. Injac R, Radic N, Govedarica B, et al. Acute doxorubicin pulmotoxicity in rats with malignant neoplasm is effectively treated with fullerenol $\mathrm{C} 60(\mathrm{OH}) 24$ through inhibition of oxidative stress. Pharmacol Rep. 2009; 61: 335-42.

56. Yang D, Zhao Y, Guo H, et al. [Gd@C82(OH)22]n nanoparticles induce dendritic cell maturation and activate Th1 immune responses. ACS Nano. 2010; 4: 1178-86.

57. Wang BB, Yang D, Sun BY, et al. An anti-tumor nanoparticle, [Gd@C82(OH)22]n, induces macrophage activation. J Nanosci Nanotechnol. 2011; 11: 2321-9.

58. Chen BX, Wilson SR, Das M, et al. Antigenicity of fullerenes: Antibodies specific for fullerenes and their characteristics. Proc Natl Acad Sci U S A. 1998; 95: 10809-13.

59. Erlanger BF, Chen BX, Zhu $\mathrm{M}$, et al. Binding of an Anti-Fullerene IgG Monoclonal Antibody to Single Wall Carbon Nanotubes. Nano Lett. 2001; 1: 465-7.

60. Braden BC, Goldbaum FA, Chen BX, et al. X-ray crystal structure of an anti-Buckminsterfullerene antibody Fab fragment: Biomolecular recognition of C60. Proc Natl Acad Sci U S A. 2000; 97: 12193-7.

61. Shintani T, Klionsky DJ. Autophagy in Health and Disease: A Double-Edged Sword. Science. 2004; 306: 990-5.

62. Wei PF, Zhang L, Lu Y, et al. C60(Nd) nanoparticles enhance chemotherapeutic susceptibility of cancer cells by modulation of autophagy. Nanotechnology. 2010; 21: 495101.

63. Li YF, Chen C. Fate and Toxicity of metallic and metal-containing nanoparticles for biomedical applications. Small. 2011; 7: 2965-80.

64. Johnston HJ, Hutchison GR, Christensen FM, et al. The biological mechanisms and physicochemical characteristics responsible for driving fullerene toxicity. Toxicol Sci. 2010; 114: 162-82

65. Yamago S, Tokuyama H, Nakamura E, et al. In-vivo biological behavior of a water-miscible fullerene: C-14 labeling, absorption, distribution, excretion and acute toxicity. Chem Biol. 1995; 2: 385-9.

66. BullardDillard R, Creek KE, Scrivens WA, et al. Tissue sites of uptake of C-14-labeled C60. Bioorg Chem. 1996; 24: 376-85.

67. Gharbi N, Pressac M, Hadchouel M, et al. [60]Fullerene is a powerful antioxidant in vivo with no acute or subacute toxicity. Nano Lett. 2005; 5: 2578-85.

68. Li QN, Xiu Y, Zhang XD, et al. Preparation of Tc-99m-C60 $(\mathrm{OH}) \mathrm{x}$ and its biodistribution studies. Nucl Med Biol. 2002; 29: 707-10.

69. Cagle DW, Kennel SJ, Mirzadeh S, et al. In vivo studies of fullerene-based materials using endohedral metallofullerene radiotracers. Proc Natl Acad Sci U S A. 1999; 96: 5182-7.

70. Wang J, Chen C, Li B, et al. Antioxidative function and biodistribution of [Gd@C82(OH)22]n nanoparticles in tumor-bearing mice. Biochem Pharmacol. 2006; 71: 872-81.

71. Baker GL, Gupta A, Clark ML, et al. Inhalation toxicity and lung toxicokinetics of $\mathrm{C} 60$ fullerene nanoparticles and microparticles. Toxicol Sci. 2008; 101: 122-31.

72. Fujita K, Morimoto Y, Ogami A, et al. Gene expression profiles in rat lung after inhalation exposure to $\mathrm{C} 60$ fullerene particles. Toxicology. 2009; 258: 47-55.
73. Chen HHC, Yu C, Ueng TH, et al. Acute and subacute toxicity study of water-soluble polyalkylsulfonated C60 in rats. Toxicol Pathol. 1998; 26: 143-51.

74. Mori T, Takada H, Ito S, et al. Preclinical studies on safety of fullerene upon acute oral administration and evaluation for no mutagenesis. Toxicology. 2006; 225: 48-54.

75. Zhao F, Zhao Y, Liu Y, et al. Cellular uptake, intracellular trafficking, and cytotoxicity of nanomaterials. Small. 2011; 7: 1322-37.

76. Yamawaki H, Iwai N. Cytotoxicity of water-soluble fullerene in vascular endothelial cells. Am J Physiol Cell Physiol. 2006; 290: C1495-C1502.

77. Marchesan S, Da Ros T, Spalluto G, et al. Anti-HIV properties of cationic fullerene derivatives. Bioorg Med Chem Lett. 2005; 15: 3615-8.

78. Mashino T, Shimotohno K, Ikegami N, et al. Human immunodeficiency virus-reverse transcriptase inhibition and hepatitis $\mathrm{C}$ virus RNA-dependent RNA polymerase inhibition activities of fullerene derivatives. Bioorg Med Chem Lett. 2005; 15: 1107-9.

79. Tegos GP, Demidova TN, Arcila-Lopez D, et al. Cationic fullerenes are effective and selective antimicrobial photosensitizers. Chem Biol. 2005; 12: 1127-35.

80. Lu ZS, Dai TH, Huang LY, et al. Photodynamic therapy with a cationic functionalized fullerene rescues mice from fatal wound infections. Nanomedicine. 2010; 5: 1525-33.

81. Srdjenovic B, Milic-Torres V, Grujic N, et al. Antioxidant properties of fullerenol $\mathrm{C} 60(\mathrm{OH}) 24$ in rat kidneys, testes, and lungs treated with doxorubicin. Toxicol Mech Methods. 2010; 20: 298-305

82. Dugan LL, Lovett EG, Quick KL, et al. Fullerene-based antioxidants and neurodegenerative disorders. Parkinsonism Relat Disord. 2001; 7: 243-6.

83. Isobe $\mathrm{H}, \mathrm{Nakanishi} \mathrm{W}$, Tomita $\mathrm{N}$, et al. Nonviral gene delivery by tetraamino fullerene. Mol Pharm. 2006; 3: 124-34.

84. Klumpp C, Lacerda L, Chaloin O, et al. Multifunctionalised cationic fullerene adducts for gene transfer: design, synthesis and DNA complexation. Chem Commun (Camb). 2007;: 3762-4.

85. Sitharaman B, Zakharian TY, Saraf A, et al. Water-soluble fullerene (C60) derivatives as nonviral gene-delivery vectors. Mol Pharm. 2008; 5: 567-78. 